\title{
PERBANDINGAN KINERJA KEUANGAN PERUSAHAAN PERKEBUNAN SEBELUM DAN SETELAH AKUISISI
}

\author{
Desi Maryanti ${ }^{*}$, Hermanto Siregar ${ }^{* *}$, dan Trias Andati ${ }^{* * *}$ \\ *) PT Performa Qualita Mandiri \\ Jl. Mayjend Ishak Djuarsa No. 226 F Gunung Batu Bogor, 16118 \\ **) Departemen Ilmu Ekonomi, Fakultas Ekonomi dan Manajemen, Institut Pertanian Bogor \\ Jl. Agatis Kampus IPB Darmaga, Bogor 16680 \\ $\left.{ }^{* * *}\right)$ PT Adhimix Precast Indonesia \\ Jl. Raya Ps. Minggu No. 17 A, Pancoran Jakarta Selatan 12780
}

\begin{abstract}
Merger and Acquisition ( $M \& A)$ conducted by estate companies listed on the Indonesia Stock Exchange (ISE) are expected to increase their competitiveness in a dynamic business environment. However, there is no consensus from previous studies on the impact of $M \&$ $A$ on the financial performance of the companies involved. This study was conducted to compare the financial performance of estate companies listed on the Stock Exchange (ISE) before and after $M \& A$. The data used were secondary data obtained from the websites of the companies, the Indonesia Stock Exchange and PT Indonesian Capital Market Electronic Library. The test was performed using paired t-test and Wilcoxon test. The results show that the values of ROA, ROE and $P B V$ of the estate companies after $M \& A$ are significantly lower than those before $M \& A$.
\end{abstract}

Keywords: mergers and acquisitions, financial performance, paired t-test, Wilcoxon test

\begin{abstract}
ABSTRAK
Merger dan akuisisi (M\&A) yang dilakukan oleh perusahaan-perusahaan perkebunan yang terdaftar di Bursa Efek Indonesia (BEI) diharapkan mampu meningkatkan daya saingnya pada lingkungan bisnis yang dinamis. Akan tetapi, tidak ditemukan adanya konsensus dari penelitian-penelitian terdahulu mengenai dampak $M \& A$ terhadap kinerja keuangan perusahaan-perusahaan yang terlibat. Penelitian ini dilakukan untuk membandingkan kinerja keuangan perusahaan-perusahaan perkebunan yang terdaftar di BEI sebelum dan sesudah M\&A. Data yang digunakan berupa data sekunder yang diperoleh dari website masing-masing perusahaan, website Bursa Efek Indonesia dan website PT Indonesian Capital Market Electronic Library. Pengujian dilakukan dengan menggunakan uji $t$ berpasangan dan uji Wilcoxon. Hasil penelitian menunjukkan bahwa ROA, ROE dan PBV perusahaan perkebunan setelah $M \& A$ signifikan lebih rendah dibandingkan $R O A, R O E$ dan PBV sebelum $M \& A$.
\end{abstract}

Kata kunci: merger dan akuisisi, kinerja keuangan, uji t berpasangan, uji Wilcoxon

\footnotetext{
${ }^{1}$ Alamat Korespondensi:

Email: desi@paqar.com
} 


\section{PENDAHULUAN}

Perkebunan merupakan salah satu subsektor pertanian yang memiliki potensi yang sangat besar dalam perekonomian Indonesia. Hal ini tidak terlepas dari posisi Indonesia yang terletak di daerah beriklim tropis sehingga memungkinkan berlangsungnya aktivitas perkebunan hampir sepanjang tahun. Data Badan Pusat Statistik (BPS) tahun 2015 menunjukkan bahwa dalam 10 tahun terakhir telah terjadi peningkatan jumlah perusahaan besar yang melakukan usaha di bidang perkebunan hingga mencapai $16,4 \%$. Itu artinya usaha tersebut dipandang sebagai bisnis yang cukup menarik dan potensial oleh para pengusaha di Indonesia.

Bagi pemerintah sendiri, perkebunan dinilai sebagai salah satu subsektor pertanian yang memiliki peran strategis di dalam pembangunan ekonomi nasional. Terbukti, selama empat tahun terakhir subsektor perkebunan selalu memperlihatkan kinerja yang positif. Data yang diperoleh dari BPS menunjukkan bahwa besarnya kontribusi Produk Domestik Bruto (PDB) yang diperoleh dari subsektor perkebunan pada periode 2012-2015 rata-rata adalah 3,7\%, dengan tingkat pertumbuhan berkisar antara 3,5-6,9\%. Selain itu, perkebunan juga mampu memberikan sumbangan terhadap devisa negara melalui ekspor KomoditasKomoditas unggulan seperti CPO, karet, kopi dan kakao senilai US $\$ 29,72$ milyar atau $95,78 \%$ dari total ekspor produk pertanian Indonesia di tahun 2014 (Pusdatin, 2015). Itulah sebabnya pemerintah masih menjadikan perkebunan menjadi salah satu subsektor pertanian andalan yang diharapkan dapat memberikan kontribusi signifikan pada pembangunan ekonomi Indonesia.

Terbukanya pasar global dan pemberlakuan Masyarakat Ekonomi ASEAN telah menyebabkan perubahan lingkungan bisnis dan tingkat persaingan di seluruh industri yang ada di Indonesia, termasuk industri perkebunan. Perubahan tersebut menuntut setiap perusahaanuntuk mengambilkebijakan yang tepat agar dapat memenangkan persaingan demi kelangsungan usahanya dalam jangka panjang. Salah satu cara agar perusahaan dapat bersaing dan berkembang dengan baik demi mencapai tujuan jangka panjangnya adalah melalui strategi pertumbuhan atau ekspansi (Lesmana dan Gunardi, 2012). Strategi tersebut dapat dilaksanakan melalui dua cara, yaitu secara internal, melalui akuisisi sejumlah aset produktif yang akan dimanfaatkan untuk meningkatkan usaha yang sudah ada, dan secara eksternal, yaitu melalui akuisisi perusahaan lain yang telah berjalan. Perusahaanperusahaan yang ingin mencapai pertumbuhan secara cepat dan meningkatkan nilai tambahnya akan memilih merger dan akuisisi (M\&A) sebagai strategi dominan perusahaan (Sinha et al. 2010).

Peningkatan aktivitas M\&A yang terjadi di beberapa negara, seperti Turki (Selcuk dan Yilmaz, 2011), Cina (Yan dan Ming, 2011) dan India (Kumara dan Satyanarayana, 2013; Sinha et al. 2010), menunjukkan bahwa M\&A masih menjadi pilihan yang menarik bagi perusahaan di seluruh dunia untuk mencapai pertumbuhan yang diharapkan. Di Indonesia sendiri aktivitas M\&A mulai marak dilakukan paska terjadinya krisis moneter tahun 1998-1999 (Suwinto, 2011). Ketika kondisi ekonomi semakin membaik, aktivitas M\&A terus berlanjut dan menjadi salah satu strategi korporasi di Indonesia. Data dari Komisi Pengawasan Persaingan Usaha (KPPU) menunjukkan bahwa aksi M\&A yang dilakukan perusahaan-perusahaan di Indonesia dalam lima tahun terakhir (2010-2014) mengalami peningkatan yang sangat signifikan, dari hanya tiga transaksi di tahun 2010 menjadi 59 transaksi di tahun 2014.

Merger dan akuisisi (M\&A) yang dilakukan perusahaan seyogyanya dapat meningkatkan kinerja keuangan sebagai hasil dari sinergi yang diperoleh dari upaya tersebut. Namun, pada kenyataannya hal itu tidak selalu terjadi. Beberapa penelitian membuktikan bahwa kinerja keuangan perusahaan setelah M\&A tidak menunjukkan perbedaan yang signifikan dibandingkan dengan kinerja sebelum M\&A, sebagaimana yang disampaikan oleh Aprilita et al. (2013), Auqie (2013), Ahmed dan Ahmed (2014) serta Inoti et al. (2014). Penelitian lainnya bahkan mampu menunjukkan adanya penurunan kinerja keuangan perusahaan setelah dilakukannya M\&A (Sinaga, 2009; Selcuk dan Yilmaz, 2011; Mulyana, 2012; Gunawan dan Sukartha, 2013). Meskipun demikian tidak semua upaya M\&A yang dilakukan perusahaan menghasilkan kinerja yang negatif. Penelitian yang dilakukan oleh Altunbas dan Marqu'es (2007), Sinha et al. (2010), serta Suwinto (2013) mampu membuktikan bahwa kinerja keuangan perusahaan justru meningkat setelah proses akuisisi.

Dari sekian banyak penelitian mengenai M\&A di Indonesia, hingga saat ini belum ditemukan satu pun penelitian yang khusus mengkaji pengaruhnya 
terhadap kinerja keuangan perusahaan-perusahaan di subsektor perkebunan, meskipun mereka cukup aktif melakukan M\&A. Sementara itu, hasil penelitianpenelitian terdahulu tidak memberikan pengaruh M\&A yang seragam pada kinerja keuangan perusahaan. Oleh karena itu, perlu dilakukan penelitian ini, yang bertujuan untuk mengkaji dampak M\&A yang dilakukan oleh perusahaan-perusahaan perkebunan tersebut terhadap kinerja keuangannya. Penelitian ini diharapkan dapat memberikan informasi yang bermanfaat bagi para pemangku kepentingan untuk mengambil keputusankeputusan yang berkaitan dengan aktivitas M\&A yang akan dilakukan di masa mendatang.

\section{METODE PENELITIAN}

Penelitian ini mencakup perusahaan-perusahaan perkebunan yang terdaftar di Bursa Efek Indonesia. Data yang digunakan merupakan data sekunder yang berasal dari laporan keuangan dan laporan tahunan perusahaan. Data-data tersebut diperoleh dari website masing-masing perusahaan, website Bursa Efek Indonesia dan website PT Indonesian Capital Market Electronic Library.

Populasi yang digunakan dalam penelitian ini adalah seluruh perusahaan perkebunan yang terdaftar di Bursa Efek Indonesia dan melakukan M\&A pada periode 2004-2011, seluruhnya berjumlah 11 perusahaan. Pengambilan contoh dilakukan dengan metode purposive judgement sampling dengan kriteria sebagai berikut:perusahaan perkebunan yang terdaftar di Bursa Efek Indonesia; melakukan M\&A minimal tiga tahun setelah IPO (go public); bulan dan tahun merger $\&$ akuisisi diketahui dengan jelas; tersedia laporan keuangan tahunan tiga tahun sebelum hingga tiga tahun setelah merger dan akuisisi.

Berdasarkan kriteria tersebut terpilih tujuh perusahaan perkebunan yang menjadi sampel dalam penelitian ini, yaitu PT Astra Agro Lestari Tbk (AALI), PT Gozco Plantation Tbk (GZCO), PT PP London Sumatera Indonesia Tbk (LSIP), PT Tunas Baru Lampung Tbk (TBLA), PT Bakrie Sumatera Plantation Tbk (UNSP), PT SMART Tbk (SMAR), dan PT Sampoerna Agro Tbk (SGRO).
Penelitian ini dilakukan untuk melihat pengaruh aksi korporasi berupa M\&A terhadap kinerja keuangan perusahaan dengan asumsi tidak ada event-event perusahaan penting lainnya pada periode pengamatan yang berpengaruh terhadap kinerja keuangan dan pengaruh variabel-variabel lain di luar M\&A dianggap tetap. Tahun diumumkannya M\&A diberlakukan sebagai tahun ke-0 (t). Analisis dilakukan dengan menggunakan data 1 tahun (t-1) hingga 3 tahun (t-3) sebelum M\&A dan 1 tahun $(\mathrm{t}+1)$ hingga 3 tahun $(\mathrm{t}+3)$ setelah M\&A terjadi (Gambar 1).

Kerangka pemikiran yang digunakan dalam penelitian dapat dilihat pada Gambar 2. Variabel-variabel yang diteliti meliputi variabel-variabel untuk menilai kinerja keuangan, yaitu tingkat leverage (DER), profitabilitas (ROA dan ROE), Economic Value Added (EVA) dan nilai pasar Price to Book Value/PBV). Agar diperoleh nilai EVA yang akurat digunakan beberapa penyesuaian pada NOPAT (laba operasi setelah pajak) dan Invested Capital (IC) mengikuti metode penyesuaian Johnson (2001). Penyesuaian untuk NOPAT dilakukan dengan penambahan increase in deferred tax reserves, Goodwill amortization dan Increase in bad debt reserves. Sedangkan nilai IC dihitung dengan menggunakan rumus berikut:

\section{$\mathrm{IC}=$ equity + Interest bearing debt + minority interest + Deferred income taxes + total goodwill amoritization + capital lease + bad debt reserve + bad stock reserve}

Adapun hipotesis substantif yang diuji dalam penelitian ini adalah H1-H5: Kinerja perusahaan perkebunan sebelum M\&A berbeda dengan kinerja perusahaan setelah M\&A

Pengujian hipotesis dilakukan dengan menggunakan uji t berpasangan apabila data berdistribusi normal, dan uji Wilcoxon apabila tidak diketahui sebaran datanya. Taraf pengujian keberartian yang digunakan adalah 5\% dan $10 \%$.

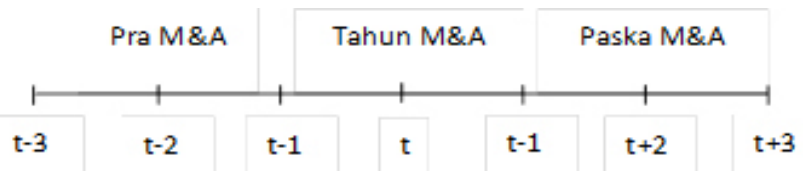

Gambar 1. Timeline analisis dampak M\&A 


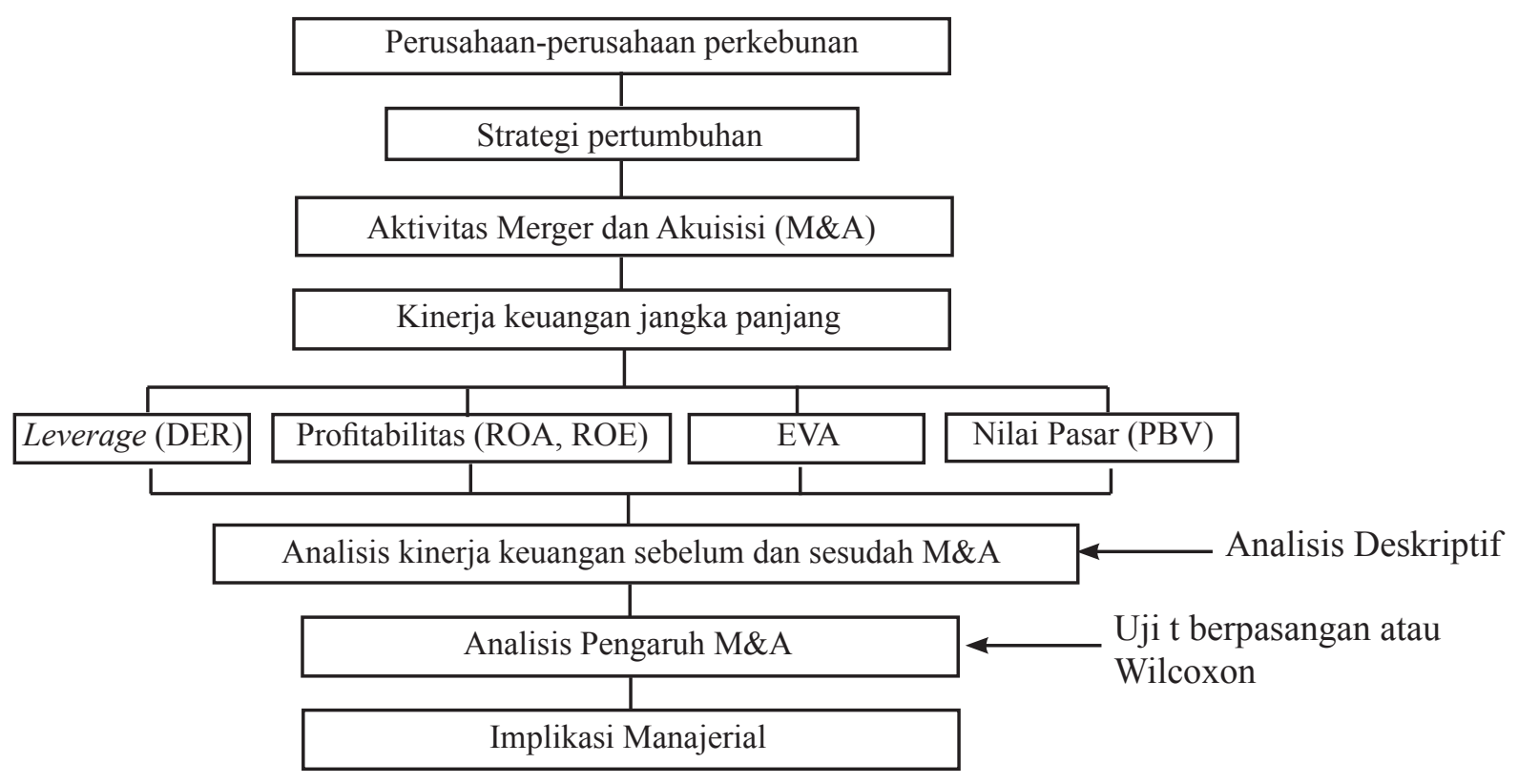

Gambar 2. Kerangka pemikiran penelitian

\section{HASIL}

\section{Deskripsi M\&A pada Perusahaan Perkebunan}

Gambaran M\&A yang dilakukan oleh masing-masing perusahaan yang menjadi obyek dalam penelitian ini disajikan pada Tabel 1. Perusahaan-perusahaan perkebunan tersebut menggunakan strategi pertumbuhan dengan melakukan akuisisi horizontal pada perusahaan-perusahaan yang bergerak dalam bidang perkebunan. Sebagian besar akuisisi dilakukan dengan tujuan untuk meningkatkan kapasitas produksi dan menambah landbank perusahaan melalui penguasaan lahan-lahan perkebunan dan pabrik pengolahan kelapa sawit. Hanya PT Sampoerna Agro Tbk saja yang melakukan akuisisi dengan tujuan diversifikasi melalui akuisisi PT National Sago Prima, sebuah perusahaan yang mengembangkan produkproduk turunan karbohidrat, untuk mengurangi risiko usaha yang terjadi pada bisnis kelapa sawit.

Meskipun beberapa perusahaan yang diakuisisi belum mulai beroperasi secara komersial seperti perusahaan yang diakuisisi oleh AALI, LSIP, dan GOZCO. Namun, penambahan aset berupa lahanlahan perkebunan dan pabrik pengolahan kelapa sawit yang terjadi melalui M\&A menggambarkan optimisme manajemen perusahaan terhadap potensi bisnis usaha kelapa sawit di masa mendatang. Menurut Nayatakaningtyas dan Daryanto (2012), peningkatan jumlah penduduk di dalam negeri dan penerapan biofuel oleh pemerintah merupakan faktor opportunity yang mendukung berkembangnya usaha perkebunan, khususnya kelapa sawit, di Indonesia yang memberikan potensi perluasan pangsa pasar untuk berbagai produk sawit beserta turunannya. Sehingga penguasaan aset berupa lahan perkebunan maupun pabrik pengolahan kelapa sawit melalui M\&A memungkinkan perusahaan untuk memenuhi kebutuhan pasar akan produk-produk tersebut.

\section{Deskripsi Kinerja Keuangan Perusahaan Sebelum dan Setelah M\&A}

Debt to equity ratio (DER) merupakan suatu ukuran kinerja yang menggambarkan struktur modal suatu perusahaan dalam membiayai operasional usahanya. DER juga digunakan sebagai ukuran leverage atau kemampuan perusahaan dalam membiayai utangnya. Semakin tinggi tingkat leverage-nya semakin besar pula risiko keuangan yang dihadapi perusahaan tersebut. Diantara perusahaan-perusahaan perkebunan yang menjadi obyek dalam penelitian ini, hanya TBLA dan UNSP saja yang memiliki nilai DER di atas 1 sebelum melakukan M\&A (Gambar 3). Hal ini menunjukkan bahwa rata-rata kemampuan perusahaan perkebunan dalam membayar utangnya sudah sangat baik. Gambar 3 menunjukkan bahwa perusahaan- perusahaan seperti AALI, GOZCO, SMAR, dan SGRO memutuskan untuk meningkatkan komposisi nilai utang terhadap modal (ekuitas) setelah dilakukannya M\&A. 
Tabel 1. Deskripsi aktivitas merger dan akuisisi yang dilakukan perusahaan perkebunan

\begin{tabular}{|c|c|c|c|c|c|c|}
\hline Emiten & Bidang Usaha & $\begin{array}{l}\text { Tanggal } \\
\text { Akuisisi }\end{array}$ & $\begin{array}{c}\text { Perusahaan } \\
\text { yang diakuisisi }\end{array}$ & $\begin{array}{c}\text { Nilai } \\
\text { perolehan }\end{array}$ & $\begin{array}{c}\text { Motif/Tujuan } \\
\text { Akuisisi }\end{array}$ & $\begin{array}{l}\text { Aset yang } \\
\text { diakuisisi }\end{array}$ \\
\hline AALI & $\begin{array}{l}\text { pengelolaan kebun dan } \\
\text { pengolahan produk- } \\
\text { produk kelapa sawit } \\
\text { serta usaha perkebunan } \\
\text { karet }\end{array}$ & 1 Mei 2011 & $\begin{array}{l}\text { PT Tri Buana } \\
\text { Mas }\end{array}$ & $\mathrm{Rp} 34,78 \mathrm{M}$ & $\begin{array}{l}\text { pengembangan } \\
\text { areal untuk } \\
\text { menciptakan } \\
\text { pendapatan di } \\
\text { masa datang }\end{array}$ & $\begin{array}{l}\text { perkebunan } \\
\text { kelapa sawit } \\
\text { yang belum } \\
\text { tertanam }\end{array}$ \\
\hline GZCO & $\begin{array}{l}\text { Pengelolaan kebun dan } \\
\text { pengolahan produk- } \\
\text { produk kelapa sawit } \\
\text { serta minyak nabati }\end{array}$ & $\begin{array}{l}28 \text { Desember } \\
2011\end{array}$ & $\begin{array}{l}\text { PT Golden } \\
\text { Blossom } \\
\text { Sumatera }\end{array}$ & Rp176,4 M & $\begin{array}{l}\text { meningkatkan } \\
\text { kapasitas operasi } \\
\text { pengolahan } \\
\text { kelapa sawit }\end{array}$ & $\begin{array}{l}\text { pabrik kelapa } \\
\text { sawit (belum } \\
\text { beroperasi) }\end{array}$ \\
\hline LSIP & $\begin{array}{l}\text { pengelolaan kebun dan } \\
\text { pengolahan produk- } \\
\text { produk kelapa sawit, } \\
\text { usaha perkebunan karet, } \\
\text { cacao dan teh }\end{array}$ & $\begin{array}{c}22 \text { Desember } \\
2008\end{array}$ & $\begin{array}{l}\text { PT Tani Musi } \\
\text { Persada, PT } \\
\text { Sumatra Agri } \\
\text { Sejahtera } \\
\text { dan PT Tani } \\
\text { Andalas } \\
\text { Sejahtera }\end{array}$ & $\mathrm{Rp} 48,05 \mathrm{M}$ & $\begin{array}{l}\text { pengembangan } \\
\text { lahan karena } \\
\text { adanya } \\
\text { kepercayaan } \\
\text { bahwa } \\
\text { permintaan } \\
\text { minyak sawit } \\
\text { akan terus } \\
\text { bertumbuh }\end{array}$ & $\begin{array}{l}\text { kebun sawit } \\
\text { seluas } 46.000 \\
\text { ha berupa lahan } \\
\text { belum tertanam }\end{array}$ \\
\hline SGRO & $\begin{array}{l}\text { pengelolaan kebun dan } \\
\text { pengolahan produk- } \\
\text { produk kelapa sawit, dan } \\
\text { usaha perkebunan karet }\end{array}$ & $\begin{array}{l}1 \text { Februari } \\
2010\end{array}$ & $\begin{array}{l}\text { PT National } \\
\text { Sago Prima }\end{array}$ & $\begin{array}{l}\text { U\$D6,48 } \\
\text { juta }\end{array}$ & $\begin{array}{l}\text { diversifikasi } \\
\text { usaha menjadi } \\
\text { produsen turunan } \\
\text { karbohidrat, } \\
\text { protein \& minyak } \\
\text { sayur yang } \\
\text { terintegrasi }\end{array}$ & $\begin{array}{l}\text { kebun sagu } \\
\text { seluas } 21.620 \\
\text { ha }\end{array}$ \\
\hline SMAR & $\begin{array}{l}\text { pengelolaan kebun dan } \\
\text { pengolahan produk- } \\
\text { produk kelapa sawit }\end{array}$ & April 2008 & $\begin{array}{c}\text { PT Sinar } \\
\text { Oleochemical } \\
\text { International }\end{array}$ & $\begin{array}{l}\text { U\$D7,015 } \\
\text { juta }\end{array}$ & $\begin{array}{l}\text { memperluas } \\
\text { keanekaragaman } \\
\text { produk minyak } \\
\text { sawit dan } \\
\text { jangkauan pasar }\end{array}$ & $\begin{array}{l}\text { pabrik } \\
\text { pengolahan } \\
\text { produk-produk } \\
\text { oleokimia }\end{array}$ \\
\hline TBLA & $\begin{array}{l}\text { pengelolaan kebun dan } \\
\text { pengolahan produk- } \\
\text { produk kelapa sawit }\end{array}$ & $\begin{array}{l}30 \\
\text { September } \\
2004\end{array}$ & $\begin{array}{c}\text { PT Agro Bumi } \\
\text { Mas }\end{array}$ & $\mathrm{Rp} 7,745 \mathrm{M}$ & $\begin{array}{l}\text { Meningkatkan } \\
\text { kapasitas } \\
\text { produksi untuk } \\
\text { memperluas } \\
\text { pasar (mengejar } \\
\text { pasar ekspor) }\end{array}$ & $\begin{array}{l}\text { pabrik } \\
\text { pengolahan } \\
\text { sawit }\end{array}$ \\
\hline \multirow[t]{3}{*}{ UNSP } & $\begin{array}{l}\text { pengelolaan kebun dan } \\
\text { pengolahan produk- } \\
\text { produk kelapa sawit }\end{array}$ & $\begin{array}{l}11 \text { Januari } \\
2007\end{array}$ & $\begin{array}{l}\text { PT Nibung } \\
\text { Arthamulia }\end{array}$ & $\mathrm{Rp} 10,35 \mathrm{M}$ & $\begin{array}{l}\text { pertumbuhan } \\
\text { jangka panjang }\end{array}$ & $\begin{array}{l}\text { pabrik } \\
\text { pengolahan } \\
\text { karet }\end{array}$ \\
\hline & & $\begin{array}{c}4 \text { Desember } \\
2007\end{array}$ & $\begin{array}{l}\text { PT Grahadura } \\
\text { Leidong Prima }\end{array}$ & $\mathrm{Rp} 1,038 \mathrm{~T}$ & & $\begin{array}{l}\text { kebun \& pabrik } \\
\text { pengolahan } \\
\text { kelapa sawit }\end{array}$ \\
\hline & & 9 Juli 2007 & $\begin{array}{c}\text { PT } \\
\text { Sumbertama } \\
\text { Nusa Pertiwi }\end{array}$ & Rp260 M & & $\begin{array}{l}\text { kebun \& pabrik } \\
\text { pengolahan } \\
\text { kelapa sawit }\end{array}$ \\
\hline
\end{tabular}




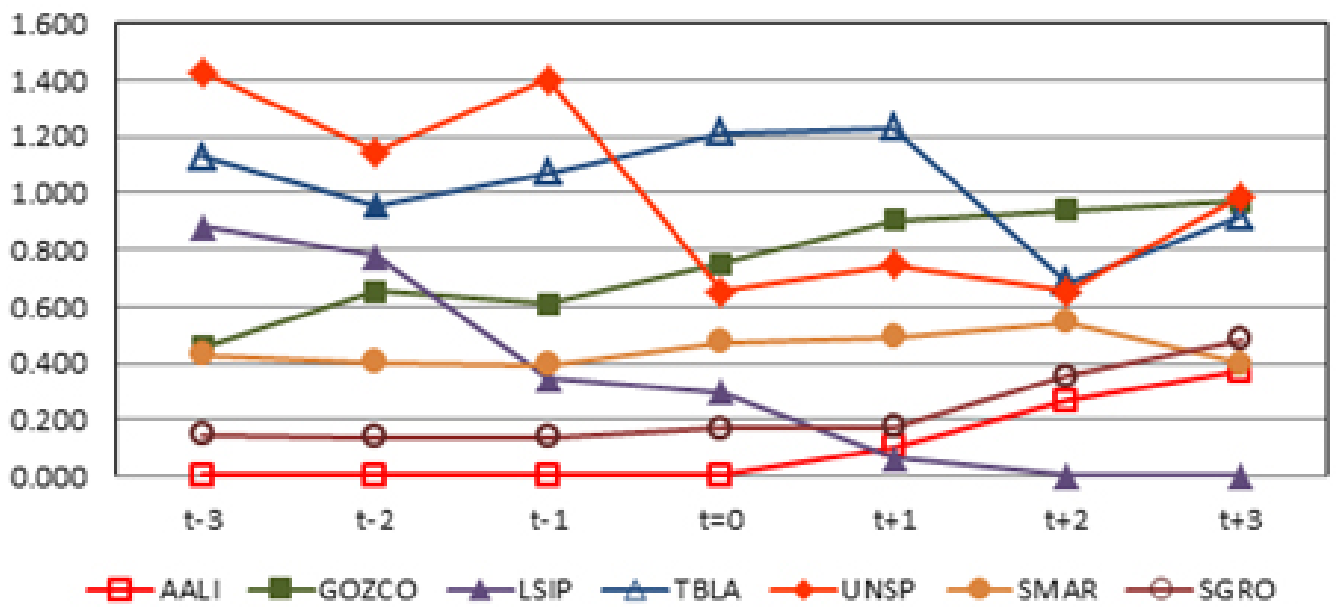

Gambar 3. Debt Equity Ratio (DER) tiga tahun sebelum dan sesudah M\&A

Seluruh perusahaan perkebunan yang menjadi obyek dalam penelitian ini, menggunakan dana kas untuk membiayai M\&A yang mereka lakukan. Agar cashflow perusahaan tidak terganggu maka salah satu pilihan logis yang dapat dipilih oleh manajemen adalah dengan mengambil dana pinjaman (utang) untuk meningkatkan kas perusahaan. Itulah sebabnya setelah M\&A dilakukan nilai DER perusahaan-perusahaan tersebut mengalami peningkatan. Meskipun demikian, peningkatan nilai DER ini berarti juga meningkatkan risiko keuangan perusahaan. Namun, selama pinjaman tersebut digunakan untuk membiayai kegiatan-kegiatan strategis yang berpotensi meningkatkan pendapatan bagi perusahaan maka keputusan untuk meningkatkan proporsi pendanaan yang berasal dari utang dapat diterima.

Untuk menilai tingkat profitabilitas atau tingkat imbal hasil dari suatu perusahaan ada beberapa rasio yang dapat digunakan, diantaranya adalah ROA dan ROE. ROA menilai tingkat imbal hasil atau laba yang dapat dihasilkan manajemen dari total aset yang dimiliki perusahaan, sedangkan ROE digunakan untuk menilai kemampuan manajemen untuk menghasilkan laba bagi para pemegang saham. Dari 7 perusahaan perkebunan yang menjadi obyek penelitian ini, hanya LSIP saja yang menghasilkan kenaikan ROA setelah M\&A dilakukan (Gambar 4). ROA TBLA dan SMAR setelah M\&A relatif stabil dibandingkan sebelum M\&A, sedangkan 4 perusahaan sisanya, yaitu AALI, GZCO, UNSP dan SGRO cenderung menunjukkan penurunan ROA setelah M\&A. Hal ini berarti bahwa setelah dilakukannya M\&A, manajemen AALI, GOZCO, UNSP maupun SGRO tidak mampu mengoptimalkan tambahan aset yang dimilikinya tersebut untuk menghasilkan peningkatan laba yang lebih tinggi daripada sebelumnya. Apalagi AALI, GOZCO dan SGRO memutuskan untuk meningkatkan proporsi penggunaan utang dalam membiayai aktivitas operasional maupun investasi paska M\&A yang mereka lakukan, seharusnya dengan peningkatan nilai DER tersebut ROA ketiga perusahaan tersebut dapat lebih tinggi dibandingkan sebelum M\&A.

Seluruh perusahaan perkebunan yang menjadi obyek penelitian ini, kecuali TBLA, menunjukkan penurunan ROE setelah M\&A (Gambar 5). Hal ini berarti, keputusan untuk melakukan M\&A yang diambil oleh manajemen perusahaan-perusahaan tersebut tidak mampu meningkatkan kesejahteraan para pemegang saham atau meningkatkan nilai perusahaan secara keseluruhan.

Gambar 6 menunjukkan bahwa AALI memiliki nilai EVA jauh di atas EVA perusahaan-perusahaan perkebunan lainnya. Selain itu hanya AALI saja yang konsisten memiliki nilai EVA di atas 0, baik sebelum maupun setelah M\&A. Meskipun demikian beberapa perusahaan selain AALI, seperti LSIP, TBLA, dan SMAR mampu meningkatkan nilai EVA-nya setelah melakukan M\&A.

Selain rasio-rasio tersebut, terdapat satu rasio keuangan lagi yang digunakan untuk menilai kinerja keuangan perusahaan perkebunan dalam penelitian ini, yaitu PBV atau price to book value. Rasio ini menunjukkan bagaimana nilai suatu perusahaan di pasar modal. Investor-investor cenderung menghindari saham-saham yang memiliki nilai PBV terlalu tinggi, karena biasanya harga saham tersebut lebih mahal dan memiliki risiko penurunan harga yang lebih besar dibandingkan saham yang PBV-nya rendah. Sebagian besar perusahaan 
perkebunan memiliki nilai PBV di atas 1, itu artinya saham-saham perusahaan perkebunan dinilai positif oleh para investor di pasar modal (Gambar 7). Namun, sayangnya aktivitas M\&A yang dilakukan mereka kurang direspon positif sehingga nilai PBV seluruh perusahaan tersebut setelah M\&A menunjukkan penurunan dibandingkan sebelum M\&A, kecuali TBLA. Karena rasio ini merupakan representasi dari tanggap investor pada setiap keputusan strategis yang diambil oleh manajemen maka ada baiknya manajemen mempertimbangkan dengan matang keputusan yang berkaitan dengan M\&A yang akan dilakukan di masa mendatang.

\section{Analisis Pengaruh M\&A terhadap Kinerja Keuangan}

Secara umum dapat dikatakan bahwa rata-rata DER perusahaan perkebunan setelah melakukan M\&A menurun jika dibandingkan dengan DER sebelum M\&A (Tabel 2). Sebelum melakukan M\&A, perusahaan perkebunan memiliki rata-rata DER sebesar 0,596, sedangkan setelah M\&A DER perusahaan sedikit menurun menjadi 0,537. Hasil pengujian pada Tabel 2 menunjukkan bahwa rata-rata nilai DER perusahaan sebelum M\&A lebih tinggi dibandingkan setelah M\&A. Namun, perbedaan diantara keduanya tidak cukup signifikan.

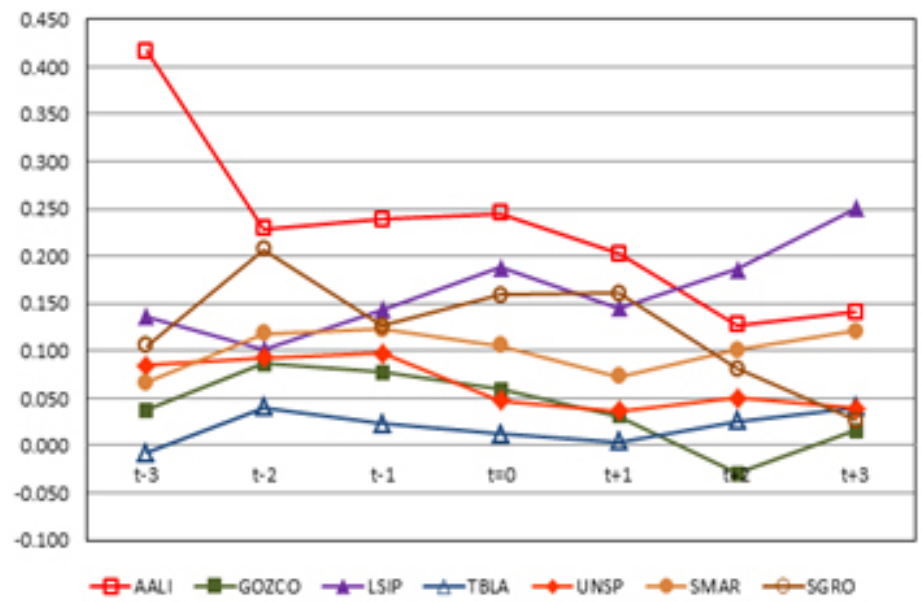

Gambar 4. Return on Asset (ROA) tiga tahun sebelum dan sesudah M\&A

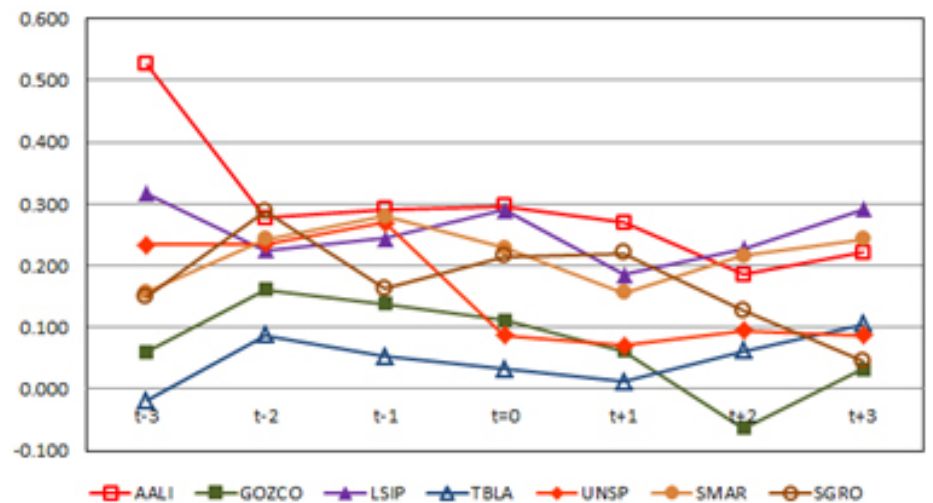

Gambar 5. Return on Equity (ROE) tiga tahun sebelum dan sesudah M\&A

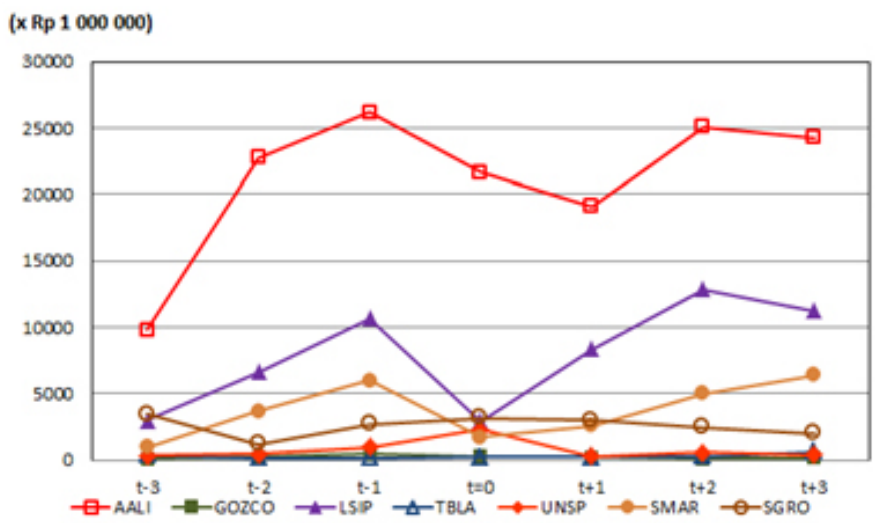

Gambar 6. Economic Value Added (EVA) tiga tahun sebelum dan sesudah M\&A 


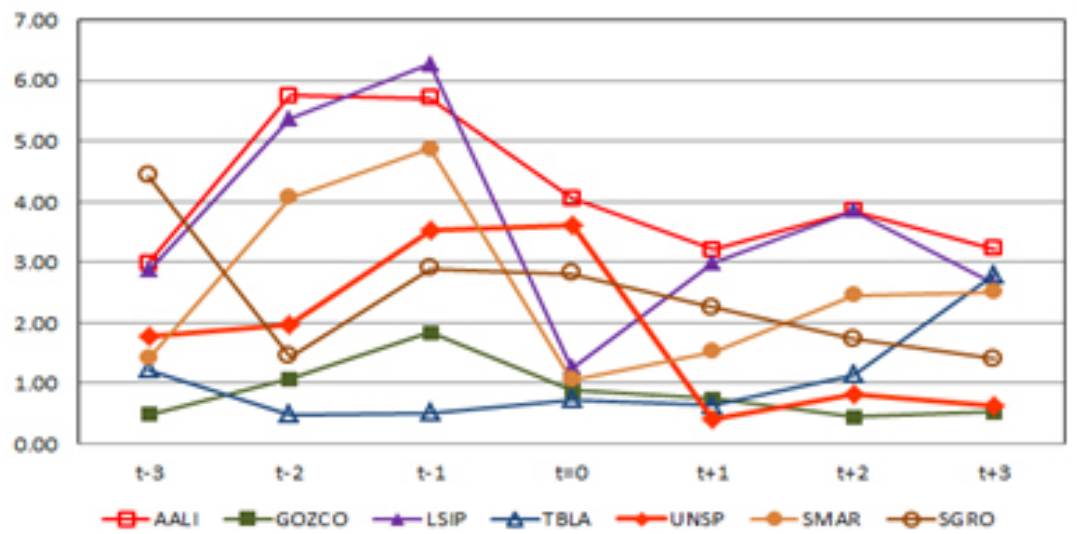

Gambar 7. Price to Book Value (PBV) tiga tahun sebelum dan sesudah M\&A

Tabel 2. Perbandingan kinerja keuangan perusahaan perkebunan sebelum dan sesudah M\&A

\begin{tabular}{lccccc}
\hline \multicolumn{1}{c}{ Perbandingan } & Mean & Stdev & Statistik uji & P value & Kesimpulan \\
\hline $\begin{array}{l}\text { DER sebelum M\&A } \\
\text { vs }\end{array}$ & 0,596 & 463 & $\mathrm{~W}=934$ & 0,307 & Tidak nyata \\
DER setelah M\&A & 0,537 & 0,366 & & & \\
$\begin{array}{l}\text { ROA sebelum M\&A } \\
\text { vs }\end{array}$ & 0.121 & 0,093 & $\mathrm{t}=-3,39$ & $0,001 \mathrm{ss}$ & Nyata \\
ROA setelah M\&A & 0,087 & 0,074 & & & \\
$\begin{array}{l}\text { ROE sebelum M\&A } \\
\text { vs }\end{array}$ & 0,209 & 0,117 & $\mathrm{t}=-5,92$ & $0,000 \mathrm{ss}$ & Nyata \\
ROE setelah M\&A & 0,136 & 0,096 & & & \\
$\begin{array}{l}\text { EVA sebelum M\&A } \\
\text { vs } \\
\text { EVA setelah M\&A }\end{array}$ & $11,97 \times 1010$ & $2,79 \times 1011$ & $\mathrm{~W}=944$ & 0,332 & Tidak nyata \\
$\begin{array}{l}\text { PBV sebelum M\&A } \\
\text { vs } \\
\text { PBV setelah M\&A }\end{array}$ & $4,65 \times 1010$ & $4,83 \times 1011$ & & & \\
\hline & 2,90 & 1,91 & $\mathrm{t}=-5,47$ & $0,000 \mathrm{ss}$ & Nyata \\
& 1,90 & 1,17 & & &
\end{tabular}

Profitabilitas perusahaan perkebunan setelah M\&A yang dinilai dengan menggunakan parameter ROA dan ROE secara umum menunjukkan penurunan dibandingkan sebelum M\&A. ROA dan ROE sebelum dilakukannya M\&A lebih tinggi dibandingkan ROA dan ROE perusahaan setelah M\&A. Hasil pengujian pengaruh M\&A terhadap ROA perusahaan perkebunan menunjukkan hasil yang signifikan sehingga dapat disimpulkan bahwa M\&A yang dilakukan tersebut berpengaruh nyata dalam menurunkan kemampuan perusahaan perkebunan dalam menghasilkan laba dari total aset yang dimilikinya (Tabel 2). Pengujian profitabilitas dengan parameter ROE menunjukkan bahwa aktivitas M\&A terbukti berpengaruh nyata menurunkan ROE perusahaan perkebunan pada taraf a 5\% (Tabel 2). Oleh karena itu, dapat disimpulkan bahwa M\&A yang dilakukan perusahaan perkebunan bukannya meningkatkan tapi justru signifikan menurunkan kesejahteraan para pemegang saham. Tabel 2 menunjukkan bahwa rata-rata EVA paska M\&A lebih rendah dibandingkan EVA sebelum M\&A. Meskipun demikian, hasil pengujian tidak menunjukkan adanya perbedaan signifikan antara EVA sebelum dengan EVA sesudah M\&A baik pada taraf $\alpha 5 \%$ maupun $10 \%$. Oleh sebab itu, dapat disimpulkan bahwa meskipun EVA perusahaan perkebunan menurun paska M\&A. Namun, karena perbedaannya tidak signifikan maka M\&A dikatakan tidak berpengaruh terhadap nilai EVA.

PBV perusahaan perkebunan setelah M\&A lebih rendah dibandingkan PBV sebelum M\&A. PBV ratarata perusahaan perkebunan sebelum M\&A adalah 2,9 sedangkan setelah M\&Anilai PBV perusahaan menurun menjadi 1,9 . Itu artinya rata-rata saham perusahaan 
perkebunan justru mengalami penurunan nilai di pasar modal setelah melakukan M\&A. Hasil pengujian statistik menunjukkan perbedaan yang signifikan antara PBV perusahaan perkebunan sebelum M\&A dengan PBV paska M\&A (Tabel 2). Oleh karena itu, secara umum dapat dikatakan bahwa M\&A berpengaruh nyata dalam menurunkan PBV perusahaan perkebunan.

Beberapa penelitian berhasil menunjukkan adanya relasi yang kuat antara tingkat leverage dengan kinerja perusahaan. Sebagian menyatakan bahwa tingkat leverage berkorelasi positif dengan kinerja seperti Akhtar et al. (2012) dan Okiro et al. (2015), sebagian lagi menyatakan sebaliknya seperti Salim dan Yadav (2012), Iavorskyi (2013) dan Rouf (2015). Pada perusahaan perkebunan, penurunan tingkat leverage paska merger dan akuisisi juga menghasilkan penurunan pada profitabilitas maupun nilai perusahaan. Dengan demikian, dapat dikatakan bahwa penurunan tingkat leverage pada perusahaan perusahaan paska akuisisi menghasilkan pengaruh yang negatif terhadap profitabilitas maupun nilai perusahaan bagi para pemegang saham.

Jika dihubungkan dengan tipikal M\&A yang dilakukan, seharusnya akuisisi horizontal yang digunakan sebagai strategi pertumbuhan oleh perusahaan perkebunan tersebut mampu meningkatkan kinerja keuangan, karena menurut teori, penciptaan nilai lebih mungkin dicapai oleh perusahaan yang melakukan aktivitas M\&A yang berhubungan (related M\&A) dibandingkan dengan yang tidak berhubungan (Korikan et al. 2014). Namun, hal itu tidak terjadi pada M\&A di perusahaan perkebunan. Merger dan akuisisi yang dilakukan perusahaan perkebunan belum berhasil mencapai sinergi seperti yang diharapkan karena beberapa faktor, diantaranya adalah pemilihan perusahaan target dan karakteristik industri perkebunan itu sendiri. Sebagian perusahaan perkebunan, memilih perusahaanperusahaan yang memiliki aset berupa lahan perkebunan belum tertanam untuk diakuisisi. Seabliknya, tanaman perkebunan, memerlukan waktu yang cukup panjang (sekitar tiga tahun) untuk memperoleh produk yang dapat dijual. Inilah yang menyebabkan perusahaanperusahaan target tersebut belum dapat memberikan kontribusi pendapatan bagi perusahaan induknya sehingga kinerja perusahaan secara keseluruhan tidak mengalami peningkatan yang signifikan. Hasil penelitian ini konsisten dengan beberapa penelitian sebelumnya seperti penelitian Auqie et al. (2013) dan Abbas et al. (2014).

\section{Implikasi Manajerial}

Penelitian ini menghasilkan implikasi manajerial bagi para manajer perusahaan perkebunan untuk rencana M\&A yang akan dilakukan perusahaan di masa depan, yaitu sebagai berikut:

Memilih perusahaan target dengan cermat

Sebaiknya para manajer perusahaan perkebunan melakukan pemilihan perusahaan target dengan cermat untuk menghindarkan penurunan kinerja perusahaan paska M\&A. Perusahaan perkebunan juga sebaiknya memperhatikan umur aset-aset yang dimilikiperusahaan target, selain akan memengaruhi produktivitas, aset-aset yang sudah tua juga membutuhkan biaya pemeliharaan yang cukup besar.

Melakukan valuasi yang benar

Para manajer sering terjebak melakukan over valuation pada perusahaan yang diakuisisinya. Terkadang, adanya persaingan dalam memperebutkan perusahaan target menyebabkan manajer perusahaan kurang mempertimbangkan nilai perusahaan yang sebenarnya. Para manajer juga seringkali terlalu berlebihan memprediksi potensi future income dari perusahaan target sehingga nilai premium yang dibayarkan untuk M\&A tersebut lebih tinggi dibandingkan hasil pendapatan yang diperolehnya kemudian.

Prioritas pengembangan pada industri hilir

Sebaiknya manajemen perusahaan perkebunan lebih memilih investasi-investasi, termasuk melakukan M\&A, yang akan memperkuat industri hilirnya. Perkuatan pengembangan industri hilir perkebunan, akan meningkatkan nilai tambah produk sehingga pada akhirnya akan meningkatkan pertumbuhan perusahaan di masa depan.

\section{Peningkatan produktivitas dengan intensifikasi}

Semakin berkurangnya ketersediaan lahan untuk usaha perkebunan, harus diantisipasi dengan upaya mengoptimalkan lahan-lahan yang telah dimiliki melalui penguasaan teknologi dan inovasi pada teknik budi daya maupun pengolahan produk-produk perkebunan itu sendiri. 
Dari perspektif calon investor M\&A yang dilakukan perusahaan perkebunan harus dinilai sebagai investasi jangka panjang. Untuk itu, bagi para calon investor yang ingin memperoleh pengembalian yang cepat dari investasi yang dilakukannya, sebaiknya menghindari investasi pada saham-saham perusahaan perkebunan yang baru melakukan M\&A. Sebaliknya, bagi para pemegang saham, adanya kecenderungan manajemen untuk lebih mendahulukan kepentingan mereka sendiri yang dapat memengaruhi keputusan M\&A perusahaan, harus dikritisi dengan mendorong dewan komisaris untuk meningkatkan pengawasan kepada manajemen perusahaan berkaitan dengan strategi M\&A yang diambilnya.

\section{KESIMPULAN DAN SARAN}

\section{Kesimpulan}

Merger dan akuisisi yang dilakukan oleh perusahaan perkebunan belum berhasil meningkatkan kinerja keuangan perusahaan secara keseluruhan. Sebagian besar parameter kinerja yang digunakan menunjukkan adanyapenurunankinerjayang dialamiperusahaanpaska M\&A. Hanya tingkat leverage saja yang mengalami perbaikan setelah perusahaan melakukan M\&A. Hal ini menunjukkan bahwa perusahaan masih memiliki potensi pertumbuhan yang baik, karena masih dapat meningkatkan kapasitas utangnya untuk dipergunakan dalam kegiatan operasional maupun investasi yang akan mendorong pertumbuhan pendapatan perusahaan di masa depan. Ketidakmampuan perusahaan perkebunan untuk mencapai sinergi dari M\&A yang dilakukan tersebut disebabkan oleh beberapa faktor, diantaranya adalah pemilihan perusahaan target dan karakteristik industri perkebunan itu sendiri. Sebagian perusahaan perkebunan, memilih perusahaan-perusahaan yang belum beroperasi secara komersial sehingga tidak dapat dengan segera memberikan kontribusi yang signifikan pada perusahaan induknya. Ukuran perusahaan yang jauh lebih kecil daripada perusahaan induknya juga, menyebabkan tambahan pendapatan yang diperoleh dari perusahaan yang diakuisisi tidak berpengaruh signifikan terhadap laba konsolidasi perusahaan secara keseluruhan. Meskipun demikian, dari M\&A yang dilakukan tersebut, perusahaan perkebunan berhasil memperoleh tambahan aset berupa lahanlahan perkebunan baru dan pabrik pengolahan kelapa sawit yang dapat dijadikan sebagai sumber pendapatan bagi perusahaan di masa depan. Selain itu, M\&A pada perusahaan perkebunan juga menghasilkan sinergi operasional berupa transfer teknologi dari perusahaan induk yang rata-rata sudah memiliki tingkat penguasaan teknologi budi daya dan pengolahan kelapa sawit yang tinggi, pada perusahaan-perusahaan yang diakuisisi. Meskipun demikian, sinergi operasional yang terjadi belum berhasil mendorong peningkatan kinerja keuangan perusahaan perkebunan yang teramati pada penelitian ini, namun di masa depan, sinergi tersebut akan menghasilkan pertumbuhan pendapatan yang signifikan setelah teknologi yang ditransfer diimplementasikan secara solid pada perusahaanperusahaan yang diakuisisi.

\section{Saran}

Penelitian ini belum mengakomodasi kemungkinan terjadinya krisis moneter yang akan berpengaruh pada harga komoditas perkebunan. Hal ini terjadi karena adanya perbedaan waktu M\&A yang dilakukan oleh masing-masing perusahaan. Sebagai perbaikan, dapat digunakan model regresi data panel, agar parameter krisis moneter dapat dimasukkan ke dalam model, sehingga menghindari bias kesimpulan. Selain itu, pengaruh M\&A pada kinerja keuangan perusahaan perkebunan juga belum dapat dievaluasi secara optimal pada penelitian ini. Karakteristik industri perkebunan yang memerlukan waktu produksi yang cukup panjang menyebabkan pengamatan pada kinerja paska M\&A yang relatif singkat pada penelitian ini diperkirakan belum dapat merefleksikan pengaruh M\&A yang sebenarnya. Penelitian selanjutnya disarankan untuk menggunakan periode pengamatan yang lebih panjang (minimal lima tahun) agar pengaruh M\&A dapat tertangkap sepenuhnya dalam kinerja keuangan perusahaan. Evaluasi keberhasilan M\&A disarankan menggunakan pendekatan operating cash flow return seperti yang dilakukan oleh Choi dan Harmatuck (2006) karena indikator tersebut dinilai lebih mampu merepresentasikan dampak ekonomis yang sesungguhnya dari akuisisi.

\section{DAFTAR PUSTAKA}

Abbas Q, Hunjra AI, Azam RI, Ijaz MS, Zahid M. 2014. Financial performance of banks in Pakistan after merger and acquisition. Journal of Global Entrepreneurship Research 4(13):1-15.

Ahmed M, Ahmed Z. 2014. Mergers and acquisitions : Effect on financial performance of manufacturing 
companies of Pakistan. Middle-East Journal of Scientific Research 21(4):689-699.

Akhtar S, Javed B, Maryam A, Sadia H. 2012. Relationship between financial leverage and financial performance: evidence from fuel and energy sector of Pakistan. European Journal of Business and Management 4(11):7-17.

Aprilita I, Tjandrakirana R, Aspahani. 2013. Analisis perbandingan kinerja keuangan perusahaan sebelum dan sesudah akuisisi (Study pada perusahaan pengakuisisi yang terdaftar di BEI 2000-2011. Jurnal Manajemen dan Bisnis Sriwijaya 11(2):99-104.

Auqie V. 2013. Dampak merger dan akuisisi terhadap abnormal return dan kinerja keuangan bidder firm di sekitar tanggal pengumuman merger dan akuisisi pada perusahaan yang terdaftar pada Bursa Efek Indonesia periode 20092012. CALYPTRA : Jurnal Ilmiah Mahasiswa Universitas Surabaya 2(2):1-16.

Choi J, Harmatuck D. 2006. Post-operating performance of construction mergers and acquisitions of the United States of America. Canadian Journal of Civil Engineering 33(3): 266-277, https://doi. org/10.1139/105-115

Gunawan KH, Sukartha IM. 2013. Kinerja pasar dan kinerja keuangan sesudah merger dan akuisisi di Bursa Efek Indonesia. E-Jurnal Akutansi Universitas Udayana 5(2):278-284.

Iavorskyi M. 2013. The impact of capital structure on firm performance: evidence from Ukraine [tesis]. Kyiv (UA): Kyiv School of Economics.

Inoti GG, Onyuma SO, Muiru MW. 2014. Impact of acquisitions on the financial performance of the acquiring companies in Kenya: A case study of listed acquiring firms at the Nairobi securities exchange. Journal of Finance and Accounting 2(5):108-115.

Johnson JM. 2001. Economic value creation in the leasing industry:A first look. Journal of Equipment Lease Financing 19(1):56-57

Korican M, Barac Z, Jelavic I. 2014. Impact of related acquisition strategy on bidding company performance. Journal of Economic and Social Studies4(2):31-51.

Kumara M, Satyanarayana. 2013. Comparative study of pre and post corporate integration through merger and acquisition. International Journal of Business and Management Invention 2(3):3138.
Lesmana FJ, Gunardi A. 2012. Perbedaan kinerja keuangan dan abnormal return sebelum dan sesudah akuisisi di BEI. Trikonomika 11(2):195211.

Mulyana B. 2012. Merger dan akuisisi bank di Indonesia tahun 1995-2008 [disertasi]. Bogor: Program Pascasarjana Manajemen Bisnis IPB.

Okiro K, Aduda J, Omoro N. 2015. The effect of corporate governance and capital structure on performance of firms listed at the East African community securities exchange. European Scientific Journal 11(7):504-533.

[Pusdatin] Pusat Data dan Sistem Informasi Pertanian. 2015. Ekspor impor Komoditas pertanian menurut subsektor.Jakarta: Kementerian Pertanian Republik Indonesia. Tersedia pada pusdatin.setjen.pertanian.go.id.

Rouf A. 2015. Capital structure and firm performance of listed non-financial companies in Bangladesh. The International Journal of Applied Economics and Finance 9(1):25-32.

Salim M, Yadav R. 2012. Capital structure and firm performance: evidence from Malaysian listed companies. Procedia - Social and Behavioral Sciences 65:156-166.

Selcuk EA, Yilmaz AA. 2011. The impact of mergers and acquisitions on acquirer performance : evidence from Turkey. Business and Economics Journal BEJ-22:1-8.

Sihna N, Kaushik KP, Chaudhary MT. 2010. Measuring post merger and acquisition performance : An investigation of select financial sector organizations in India. International Journal of Economic and Finance 2(4):190-200.

Sinaga RA. 2009. Analisis pengaruh merger akuisisi terhadap kinerja keuangan perusahaan pengakuisisi di Bursa Efek Indonesia [tesis]. Bogor: Sekolah Pascasarjana Manajemen Bisnis IPB.

Suwinto Johan. 2011. Implementasi strategi bisnis dan korporasi melalui merger dan Akuisisi. Ultima Manajemen. 3(1).

Yan L, Ming L. 2011. The analysis on non-economic influencing factors in transnational merger made by Chinese energy firms based on ESP paradigm. Energy Procedia 5: 69-73.

Nayantakaningtyas JS, Daryanto HK. 2012. Daya saing dan strategi pengembangan minyak sawit di Indonesia. Jurnal Manajemen \& Agribisnis 9(3):194-201. 